\title{
The role of the myostatin protein in meat quality - a review
}

\begin{abstract}
Summary
The myostatin protein is a regulator factor in the normal muscle that determines the maximum amount of muscle mass that is typical of that species. If the myostatin gene is mutant, the negative regulating function of the gene does not work. This leads to an increased muscle growth resulting in muscle hypertrophy and hyperplasia. That phenomenon occurs in beef cattle production as well, e.g. in Belgian White-Blue breed where the 'doublemuscled' phenotype is common due to the successful selection. In the view of quality meat production, this is an outstanding trait, since these animals produce not just more, but better: leaner and tenderer meat. Crossing with Belgian White-Blue cattle shows that although the gene is recessive and monofactorial, its effect is apparent even in heterozygotes due to its partial dominance: the meat:bone ratio and meat yield is better than those of the other breed. In animals with a Culard phenotype this trait manifests with others: there are less fat and suet deposited and the amount of connective tissues between muscles are also decreased.
\end{abstract}

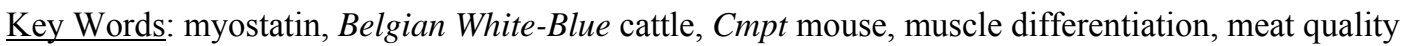

\section{Zusammenfassung}

Titel der Arbeit: Die Rolle des Eiweißes Myostatin für die Fleischqualität - eine Übersicht

Das Eiweiß „Myostatin“ bestimmt im normalen Muskelgewebe die für die Rasse charakteristische, maximale Muskelmasse. Wenn das Gen mutiert, kann seine negative Regulierungsfunktion nicht zur Geltung kommen, was zu erhöhtem Muskelwachstum, Muskelhypertonie und Hyperplasie führt. Dieses Phänomen ist auch bei der Zucht von Fleischrindern anzutreffen. Die Rasse Belgian White Blue (BWB) zeigt z.B. infolge der spezifischen Selektion in erhöhtem Masse den Doppellender im Phänotyp. Aus der Sicht der Qualitätsfleischproduktion handelt es sich um eine außergewöhnliche Eigenschaft, da diese Tiere nicht nur mehr Fleisch produzieren, sondern dieses auch von einer besseren Qualität d.h. magerer und zarter ist. Die verschiedenen Kreuzungen mit der Rasse BWB zeigen, dass das Gen rezessiv und monofaktorial vererbt wird, seine Wirkung jedoch auch bei heterozygoten Formen zur Geltung kommt. Das Knochen/Fleisch-Verhältnis und der Fleischertrag der Schlachttiere sind besser als bei Tieren der anderen Anpaarungsrassen und deren Kreuzungen. Bei Tieren mit dem „Culard“ Phänotyp tritt diese Eigenschaft gemeinsam mit geringerer Fett- und Talgablagerung und niedrigeren Bindegewebsanteilen zwischen den Muskeln auf.

Schlüsselwörter: Myostatin, Belgian White-Blue Rasse, Cmpt Maus, Muskeldifferenzierung, Fleischqualität

\section{Introduction}

Meat production still has the greatest proportion within animal production. However, not only quantity but quality is very important in meat industry. Nutritional and physiological research investigating the effects of meat components (even at macromolecular level) is more and more important. The genetic factors (i.e. heritable traits) have an outstanding role among factors that determine meat quality. The phenomenon of muscular hypertrophy is documented in several species including cattle. In such animals, the skeletal muscles in adults become oversized. The phenotype of these animals is well recognisable: they have huge, overdeveloped muscles generally all over the body and their body weight is significantly higher. In animals expressing muscular hypertrophy, an approximately $20 \%$ increase can be 
observed in the mass of the skeletal muscles. Growth affects all skeletal muscles all over the body. According to experiments, the growth of the skeletal muscles can hardly be explained by the increase in the diameter of the muscle filaments only (hypertrophy), but rather with the increased number of filaments of each muscle (hyperplasia; HANSET et al., 1982). In spite of this fact, everybody refers to this phenomenon as a muscle hypertrophy!

The culard type has been known for a long time in cattle breeding (CULLEY, 1807, cit. MÉNISSIER, 1982; KAISER, 1888, cit. MÉNISSIER, 1982). Such animals were always sought after in beef cattle production as a significant source of meat. Therefore, these mutations were fixed and passed from one generation to the next. The best example is the meaty type ('viande') of Belgian White-Blue cattle that are homozygous for the mutation, because the goal of the selection was to keep and propagate the animals carrying the muscular hypertrophy (HANSET, 1997). Now, it is known that the main factor responsible for the culard phenotype is the myostatin gene (MCPHERRON and LEE, 1997). In this paper, the role of myostatin, and its importance in meat production is reviewed.

The discovery of the myostatin

In spite of several investigations, the genetic cause of the muscular hypertrophy remained unknown for a long time. Although, the first written document about the 'double muscled' cattle dates back to 1807 (CULLEY, 1807, cit. MÉNISSIER, 1982), the consequent observation of the inheritance of the trait did not reveal more than a speculation: it is probably a monogenic, autosomal and partially recessive trait, with an incomplete penetrance (MÉNISSIER, 1982). It was only in 1995, when the supposed gene was found in the $\mathbf{q}$ arm of the bovine chromosome 2, approximately $2 \mathrm{cM}$ from the marker TGLA44. The locus was named mh (muscular hypertrophy; CHARLIER et al., 1995). This finding was proved with FISH (Fluorescent In Situ Hybridisation; SMITH et al., 1997) as well. Although mapping was continued, an incident led to the discovery of the genetic background. The members of the TGF- $\beta$ (Transforming Growth Factor) family were studied in mouse as a model animal. Using gene-targeting (knock-out), the GDF-8, also known as myostatin, was removed from the genome of the mouse. The null-mutant mice showed muscular hypertrophy and hyperplasia i.e. their muscularity showed a considerable growth (MCPHERRON et al., 1997). After this experiment, it was investigated, whether the mutation of the same gene responsible for the muscular hypertrophy was found in individuals of other species, e.g. cattle.

The investigation began on different breeds by three groups: every group studied the Belgian White-Blue cattle, well known for its double muscled phenotype. While two of the groups also studied DNA-samples of individuals of Piedmontese breed showing muscular hypertrophy (KAMBADUR et al., 1997; MCPHERRON and LEE, 1997), the third group studied other breeds as well, where overmuscled animals were found (Asturiana, Maine-Anjou; GROBET et al., 1997).

The myostatin gene became a candidate gene responsible for double-muscling phenotype. After cloning the bovine myostatin gene, its alleles were localised at the $\mathrm{mh}$ locus in the $\mathbf{q}$ arm of chromosome 2, close to the centromeric region (BTA2q12-22 region; SMITH et al., 1997). The direct sequencing of the myostatin gene of the Belgian White-Blue and Asturiana cattle breeds revealed an $11 \mathrm{bp}$ deletion in the 
coding region [nt821(del11)]. The deletion leads to a frameshift mutation that causes a stop codon after the amino acid 287. This mutation results in a truncated, inactive protein (GROBET et al., 1997; KAMBADUR et al., 1997; MCPHERRON and LEE, 1997). In the same region of the protein, where a deletion was found in the Belgian White-Blue, there is a $\mathrm{G} \rightarrow \mathrm{A}$ transition in the Piedmontese. That transition exchanges one of the cysteins to tyrosine that probably prevents normal functioning of the protein. The amino acid sequence of this region of the protein is strongly conserved in the TGF- $\beta$ family of transcription factors as well as in other species (KAMBADUR et al., 1997; MCPHERRON and LEE, 1997). In their first experiment GROBET and his colleagues did not find the nt821(del11) mutation in the Maine-Anjou breed (GROBET et al., 1997), but later they extended their examinations to other mutations and to other breeds as well (GROBET et al., 1998). MCPHERRON and LEE investigated if the nt821(del11) mutation was present in other non-double-muscled breeds, but only polymorphism has been found which does not affect the amino acid sequence of the myostatin protein (1997).

Therefore, it was proved that the culard phenotype, well-known for ages and preferred in beef cattle production, is caused by the mutation of the myostatin gene.

\section{Myostatin: a transcription factor?}

The myostatin protein plays an important role in the control of the development of the skeletal muscles. It is a member of the Transforming Growth Factor- $\beta$ (TGF- $\beta$ ) superfamily that includes a group of growth and differentiation factors. These play a great part in regulating the embryonic development and tissue homeostasis (KINGSLEY, 1994; MCPHERRON and LEE, 1996). A typical feature of the transcription factor proteins that belong to this family is that their amino acid sequence is conserved among species. These proteins always contain a secretion signal, a proteolitic processing site and cystein residues in their carboxyl-terminal regions. This cystein-rich region serves as a linker region between two molecules, so these proteins are capable to form homodimers through this region (MCPHERRON and LEE, 1996). The myostatin or GDF-8 (Growth/Differentiation Factor-8) functions as a negative regulator during muscle growth: it determines the skeletal muscle mass of a given species. Its mutation leads to the 'double-muscled' phenotype. The protein of myostatin bears all the characteristics of the TGF- $\beta$ family: it has a secretion signal near to the N-terminus, a proteolitic processing site in the $\mathrm{C}$-terminal region (RSRR, 263-266 amino acids) and nine cystein residues also in the C-terminal region of the protein, which is important in the dimerisation process (MCPHERRON et al., 1997). The propeptid of the myostatin is 376 amino acid long which becomes a $26 \mathrm{kDa}$ active peptide after the proteolitic process (MCPHERRON et al., 1997; SHARMA et al., 1999).

In the mouse, the expression can be detected mainly in the skeletal muscle. First it can be observed at day 9.5 p.c. In adult animals, the expression also exists in skeletal muscles but with a lower expression level in the adipose tissue (MCPHERRON et al., 1997). In preadipocyte tissue cultures, the addition of myostatin protein inhibits the differentiation of these cells. During the treatment, the glycerol-3-phosphate dehydrogenase (GPDH), the CCAAT/enhancer binding protein alpha (C/EBP alpha) and the peroxisome proliferator-activated receptor gamma (PPAR gamma) activity was reduced (KIM et al., 2001). Although, the mechanism is not clear, this expression 
pattern may explain the decrease in fat production of the myostatin mutation carrier cattle.

Recent publications revealed that the mRNA (or the protein) of the myostatin were detectable in other tissues. It was also found in cardiomyocytes and in Purkinje fibres of the heart with immunostaining (SHARMA et al., 1999). In pigs, the mRNA of the myostatin was detectable in the tissue of the mammary gland besides the skeletal muscle expression. However, the role of this phenomenon was not investigated yet (SHAOQUAN et al, 1998).

In the end of the last year, THOMAS et al. (2000) demonstrated that the myostatin functions as an inhibitor factor for muscle cell proliferation. In their experiment, when myoblast cultures were incubated with myostatin, the proliferation of the cells was inhibited in a dose dependent manner. When the myostatin protein was removed from the culturing medium, the cells began to proliferate again. The role of the myostatin in the cell cycle was also examined. It was found that a low percentage of the cells were in phase $\mathrm{S}$ during the treatment with myostatin protein. It means that the myostatin blocks the cell cycle in $\mathrm{G} 1$ and $\mathrm{G} 2 / \mathrm{M}$ phase. It up-regulates the cyclin-dependent kinase $(\mathrm{Cdk})$ inhibitor p21 protein, but does not affect any other p21 or p16 family member. It also affects the level of the Cdk2 protein: it is down-regulated during the myostatin treatment. The myostatin decreases the phosphorilation of the retinoblastoma protein $(\mathrm{Rb})$, which is known as a major substrate of the Cdks in the G1 phase. These results indicate that the myostatin blocks the cell cycle through these molecules (THOMAS et al., 2000). It is proposed that the hyperplasia observed in the Belgian White-Blue cattle or in the knock-out mice by MCPHERRON and colleagues is the result of a deregulated myoblast proliferation (1997).

Genetic analysis of muscular hypertrophy in various cattle breeds

Muscular hypertrophy has been reported not only in Belgian White-Blue and Piedmontese but in other breeds as well. In the Asturiana breed of Spain and in the Maine-Anjou of France, the gene responsible for hypertrophy was located in the $m h$ locus (GROBET et al., 1997). However, the gene itself was not identified before myostatin was discovered. After the myostatin was found, the survey was extended to several cattle breeds, in which hypertrophy with different frequency has already been reported. The mutation of the myostatin gene was proved in Belgian White-Blue, Piedmontese and Asturiana as mentioned earlier. Thus, six other European breeds were included in the study: the Blonde d'Aquitaine, the Charolais, the Gasconne, the Limousin and the Parthenais from France and the Rubia Gallega from Spain. The samples of breeds identified earlier as carriers were also used (the Belgian White-Blue, the Piedmontese, the Asturiana and the Maine-Anjou). Samples of Holstein-Friesian were used as controls.

In the study, positional cloning and direct sequencing were used. The mutations of the myostatin gene were identified in all but two breeds. Five different mutations were found. One of them was always found in homozygotic form in animals with muscular hypertrophy. The two exceptions were the Limousin and the Blonde d'Aquitaine. In these breeds, although different mutations were found in their myostatin gene, there was no unequivocal evidence of linkage with muscular hypertrophy. According to a hypothesis, it may be due to a mistake in the posttranscriptional or posttranslational modification of the protein or a mutation of another gene(s) (GROBET et al., 1998). 


\section{Other species}

Shortly after the discovery of the myostatin, MCPHERRRON et al. (1997) identified the myostatin gene in several breeds besides the Belgian White-Blue cattle. The sequence of the myostatin of the baboon, chicken, ovine, porcine, rat, turkey, zebrafish and of the human was published. These show that the amino acid sequence of the myostatin transcription factor is strongly conserved among species. After the proteolitic processing site, the sequence is $100 \%$ conserved comparing the mouse, rat, human, porcine, chicken and turkey, while that of the baboon, ovine and bovine differs in 1-3 amino acids. Only the protein of the zebrafish is more divergent: in this region it is identical only in $88 \%$ with that of the others (MCPHERRON et al., 1997).

Most information about myostatin and its role were gained from mouse and cattle, but similar studies are conducted in other species as well. In rats, the role of the myostatin and the effect it exerts in muscle regeneration was investigated by several authors. It could be concluded from the experiments that the level of myostatin increases during the regeneration period, which suggests the up-regulation of myostatin expression (KIRK et al., 2000; MENDLER et al., 2000; SAKUMA et al., 2000; YAMANOUCHI et al., 2000; TAYLOR, 2001).

Muscle fibre type selective expression could be detected in rats: the myostatin mRNA was absent in the slow type (MyHC type I) fibres (KIRK et al., 2000). The results of the experiments on muscle precursor cells (satellite cells) in chicken differed from these findings. No significant difference was found in the level of myostatin mRNA between the muscles expressing red or white fibres. In addition, that level proved to be stable during cleavage (KOCAMIS et al., 2001). Earlier publications (although, those experiments were made on non-chicken tissue-culture) stated that the high level of myostatin blocks the cleavage of myoblasts (CARLSON et al., 1999). KOCAMIS explains the difference with the mixed muscle tissue culture that CARLSON and other authors used instead of pure satellite cell culture. He states that the myostatin mRNA content of the satellite cells is different from that of the matured cells (KOCAMIS et al., 2001). On the other hand, the difference may be a result of an alternative posttranslational modification of myostatin in different muscle fibre types as found in rats (WEHLING et al., 2000).

In swine, the myostatin gene is located on the $\mathbf{q}$ arm of chromosome 15 (SONSTEGARD et al., 1998). Investigating several breeds (Yorkshire, Meishan, Hampshire, Duroc) only polymorphism were detected in the DNA sequence of the gene which does not cause any change in the protein level (STRATIL and KOPECNY, 1999). This means that there is no relation between the myostatin and the outstanding meat production of these breeds. During the study of its expression pattern, a mammary gland specific expression was observed besides the skeletal muscle specific expression (JI et al., 1998). However, the importance of this observation was not recognised.

In fishes, the gene was identified in the Atlantic salmon (Salmo salar) and in the carp (Cyprinus caprio) but no mutation was found. The sequence analysis was not published in a scientific journal but in the GeneBank database of the Internet. In our observation, the amino acid sequences show a high homology with that of the zebrafish (Danio rerio) and they differ from those of the higher vertebrates to a similar extent. RODGERS and his co-workers (2001) isolated the myostatin gene from two other fish species: the tilapia (Oreochromis mossambicus) and the white bass (Morone 
chrysops). They have found that the sequence of the protein is highly homologous with those identified earlier. However, a different expression pattern was recognised: the myostatin expression was not limited to the skeletal muscle, but it was found in several tissues (RODGERS et al., 2001).

At the same time, another publication on fish reported the isolation of two myostatin isoforms: the two forms show a $92 \%$ identity at the nucleotide level. One of its was isolated from the muscle and the brain of the brook trout (Salvelinus fontinalis) while the other from the ovarian tissues. In the brain, they localised the myostatin expression in the optic lobes, the hindbrain and the hypothalamus. The ovarian isoform of the myostatin shows an increase in ovulating females. Four other fish species were drawn into the experiments with the same results (ROBERTS and GOETZ, 2001). The other interesting observation was that the myostatin expression was localised in the red muscle tissue (slow fibres) specifically in three species, while in two other species different patterns were observed (ROBERTS and GOETZ, 2001). These findings indicate that the myostatin might have different roles in fishes than in higher vertebrates.

\section{Cmpt mouse and myostatin studies}

As mentioned earlier, the search for the genes that cause a typical phenotype in 'double-muscled' cattle began before the myostatin was discovered. The 'doublemuscle' phenotype was reported in the mouse (as genetic model animal) as well. The so-called 'Compact' (Cmpt) mouse has a similar phenotype with that of the Belgian White-Blue. Significant difference was found between the affected and the 'normal' animals in carcass \% and bone:meat ratio. A mouse strain was selected for high body mass and protein content, when the Cmpt phenotype was first recognised. Then, the Compact subline was separated and bred selectively. The candidate gene which is responsible for the Cmpt phenotype was located at the chromosome 1 of the mouse by linkage mapping (VARGA et al., 1997).

When the myostatin gene and the phenotype caused by its deficiency was reported, SZABÓ and his colleagues tested the Cmpt mouse for the myostatin candidate gene. They found that the gene which is responsible for the Cmpt phenotype is the myostatin. They cloned and sequenced the gene and found a 12-bp deletion in the coding region of the gene. It caused a five amino acids deletion and a new amino acid in the peptide chain. The mutation affects the proteolitic process site, thus, the 3D structure of the protein changes. Therefore, the activity of the protein is greatly reduced (SZABÓ et al., 1998). It was also noticed that Cmpt shows a partial dominance in males and fully recessive in females. This was explained with the effect of modificator genes (or loci) (SZABÓ et al., 1998).

The role of myostatin in meat production

As we mentioned earlier, the muscular hypertrophy is due to the increase in the diameter of the muscle filaments and increased number of filaments of each muscle (hypertrophy and hyperplasia; HANSET et al., 1982). Besides the increase in muscle mass, other favourable properties appear in these animals. There is a $50 \%$ reduction in total lipid content (the stout deposits in cavities also decrease) and the connective tissue is also reduced. This results in a leaner and tenderer meat with a significantly improved consume value. 
In the null mutant mouse, a muscle type specific hypertrophy was observed: a different degree of hypertrophy was noticed in different muscles. The mRNA levels measured in control animals were in accord with the hypertrophy measured in the same muscle of a null mutant: the weight of a muscle with an otherwise low level of myostatin expression was greater in animals with hypertrophy compared with muscles with normally high level of myostatin expression (MCPHERRON et al., 1997). This was also proved by CARLSON et al. (1999). It was found that myostatin expression is fibre type specific. Its level is higher in fast muscles than in slow type of muscles. It correlates with the Myosin Heavy Chain (MyHC) isoforms: a correlation was detected between the level of myostatin mRNA and the percentage of MyHC IIb in muscle (CARLSON et al., 1999). The fibre specific expression of the myostatin may be related to its function because it affects the proliferation of myoblasts (THOMAS et al., 2000), but the number of satellite cells (muscle precursor cells) is lower in fast (MyHC I type) muscles (GIBSON and SCHULTZ, 1982). For the meat industry, it means that in animals with muscle hypertrophy, those muscles composed predominantly of fast fibres will show a considerable growth.

The bone:meat ratio is also more favourable in affected animals than in the control ones. It is also expressed in the better meat gain projected to the body weight. In null mutant mouse, no significant difference was found in the skeleton. Local deviations were found in the attachment of the increased muscles to the bones, e.g. the hindlimb muscles that approximately doubled their mass that caused an enlargement of the trochanter on the femur, but induction of additional cortical bone deposition in the diaphysis was not observed (HAMRICK et al., 2000). These results demonstrate that if body weight is increased, the skeletal system will not show a similar enlargement. That explains the fact that the total amount of bones does not decrease in animals with hypertrophy (e.g. in cattle), just does not follow the increase in the body weight as it would happen in animals with normal genotype (i.e. heavier animal requires stronger bones). This is the cause of the better bone:meat ratio observed in slaughter. It can be concluded that the myostatin does not affect bone development.

Use of myostatin mutant breeds in beef cattle production

Since the culard phenotype occurs most frequently in the Belgian White-Blue, the breed requires a detailed analysis. The culard phenotype of this breed manifests with partial dominance and improper penetrance (although, its known as a trait with a monofactorial inheritance due to the mutation of the myostatin gene). However, experience shows that penetrance can be increased by selection. According to certain views, the mutation of myostatin is the main cause of hypertrophy, but there are probably other genes as well that contribute to its complete manifestation. It is validated by the observation that the phenotype of the double-muscled individuals of the Belgian White-Blue produce more mass of muscle than 20 years ago (CHARLIER et al., 1995). This, of course, is caused by the increasing number of genes fixed in the homozygous form due to planned selection (it can also be stated that this breed is more inbred than two decades ago). The mutation of one gene alone can not be responsible for such a change in the phenotype (HANSET, 1997).

Unfortunately, the breeding of animals expressing muscular hypertrophy can be problematic. Breeders often have to face with calving difficulties due to large calf 
weight and the anatomical distortion of the mother. That explains why the Belgian White-Blue is not bred in a large scale all over the world (DICKMAN, 1997).

Therefore, the Belgian White-Blue is usually used in crossings in beef cattle production as a terminal breed. The effect of the mutation on the appearance of the progeny is very pronounced. In utility crossings, the Belgian White-Blue was found to improve many traits related to meat production and meat quality. It has already been used in several international comparison tests. These results show that this breed is an excellent candidate as a terminal sire. They produced about five to ten percent more retail product than other breeds in the comparison tests (CUNDIFF et al., 1997; CASAS et al., 1999).

In Hungary, similar comparison tests were performed by the Hungarian Association of Belgian White-Blue Cattle Breeders. When Belgian White-Blue was crossed with a dairy type cattle (Holstein-Friesian) the progeny had better carcass weight $(+11 \%)$, lean meat weight $(+17.7 \%)$, and the daily gain also increased. The bone:meat ratio decreased. The quality of meat also improved, as the separable intermuscular fat decreased by almost ten percent. The $\mathrm{F}_{1}$ was better in feeding efficiency as well: $20 \%$ less fat was produced from the feed and deposited in body cavities than pure-bred HF (BÖLCSKEY et al., 1996). In crossings with beef (Lincoln Red), carcass composition was greatly improved (BÖLCSKEY et al., 1997a). The percentage and amount of inter- and intramuscular fat was significantly reduced (20-30\%) which can be well utilised in crossing with beef having a tendency to fatness. The protein and dry matter content of meat remained unchanged (BÖLCSKEY et al., 1997b). In dual purpose cattle (Hungarian Simmental) Belgian White-Blue improves carcass weight, body composition, and dressing percentage (BÖLCSKEY et al., 1999b). The breed can improve meat production with ancient breeds as well. Crossing with Hungarian Grey, the $F_{1}$ was considerably better in weight gain during fattening (i.e. low-cost calf rearing), dressing percentage and body composition (BÖLCSKEY et al., 1999a).

In the heterozygotes, the meat:bone ratio and the meat yield and quality is significantly better than in the unaffected breed used in the crossing. Calving difficulty ceases in heterozygotes. The real value of the breed lies in its improving effect exerted in crossings proved by national and international surveys in several types and breeds (DOHY, 1979; CASAS et al., 1999).

\section{Future perspectives}

Although, our knowledge about myostatin and muscle development is constantly growing, there are still many questions to be answered.

According to certain views, the myostatin might be a target gene for increasing the muscle mass, because its manipulation probably does not interfere with other growth systems (WESTHUSIN, 1997). Therefore, more meat can be produced in the livestock industry. Others state that the myostatin protein can be a tissue-specific inhibitor molecule that control the growth of the skeletal muscle. To prove this, it should be known if the myostatin is a circulating molecule or not (SLACK, 1997). However, it is not known if it acts as a systemic or as a local inhibitor. It is even not known if it works as a transcription factor or it has other control function (LEE and MCPHERRON, 1999).

THOMAS and his colleagues showed that the myostatin is a negative regulator acting through the inhibition of myoblast proliferation (2000). In their model, there are some 
questions to be answered: how the myostatin can influence the level of p21, and what is the mediator factor between myostatin and p21? They also found a cell cycle arrest at the boundary of $\mathrm{G} 2 / \mathrm{M}$ which is currently under investigation. The authors also raise the question if this repression can be mediated by $\mathrm{p} 21$.

A fibre-type selective expression of myostatin was found, which is probably related to the MyHC type of muscle fibres (KIRK et al., 2000). A question arises: what mechanism control the expression of myostatin in this manner? Besides the mouse, several experiments prove that the expression of myostatin is not restricted to the skeletal muscles. It also can be found in cardiomyocytes and in Purkinje fibres of the heart (SHARMA et al., 1999), in the adipose tissue (MCPHERRON et al., 1997), in porcine mammary gland tissue (JI et al., 1998), and in several tissues of many fish species (ROBERTS and GOETZ, 2001; RODGERS et al., 2001). These findings indicate that the myostatin has other role besides the regulation of the skeletal muscle mass. However, no one has elaborated a possible explanation of the occurrence of the myostatin in non-muscle tissues.

The authors currently work together with the group that described the Cmpt mutation. Their goal is to identify the factors that are involved in the muscle cell differentiation in relation with the myostatin factor. Muscle cell cultures are used to test the role of muscle specific transcription factors (MyoD, Myogenin, Mrf4) and muscle proteins in the interaction with myostatin. It is hoped that the interacting points of myostatin and other genes/proteins which are responsible for the regulation of myoblast proliferation and differentiation will be found.

\section{Acknowledgement}

The authors wish to express their gratitude to Prof. J. Dohy for his help in the preparation of the manuscript. The kind help and the breeding data from K. Bölcskey and the Hungarian Association of Belgian White-Blue Cattle Breeders were essential for this work.

\section{References}

BÖLCSKEY, K.; BÁRÁNY, I.; BODÓ, I.; BOZÓ, S.; GYÖRKÖS, I.; LUGASI, A.; SÁRDI, J.; BOZÓ, S.; GYÖRKÖS, I.:

Utility crossing using Belgian White blue and Charolais semen in Hungarian Grey Herds. Book of Abstracts of the $50^{\text {th }}$ Annual Meeting of the European Association for Animal Production, Zurich, Switzerland, 22-26 Aug. 1999., Wageningen Pers, Wageningen, The Netherlands, (1999a), 202

BÖLCSKEY, K.; BÁRÁNY, I.; BOZÓ, S.; GYÖRKÖS, I.; SÁRDI, J.:

Commercial crossing with Belgian White Blue semen in Hungarian Simmental herds. Book of Abstracts of the $50^{\text {th }}$ Annual Meeting of the European Association for Animal Production, Zurich, Switzerland, 22-26 Aug. 1999., Wageningen Pers, Wageningen, The Netherlands, (1999b), 203

BÖLCSKEY, K.; SÁRDI, J.; BOZÓ, S.:

Utility crossing with Belgian White-Blue cattle in a Holstein-Friesian herd. Book of Abstracts of the $47^{\text {th }}$ Annual Meeting of the European Association for Animal Production, Lillehammer, Norway, 25-29 Aug. 1996., Wageningen Pers, Wageningen, The Netherlands, (1996), 203

BÖLCSKEY, K.; SÁRDI, J.; BOZÓ, S.; GẢSPÁRDY, A.:

Commercial crossing using Belgian White-Blue semen in a Lincoln Red herd. Book of Abstracts of the $48^{\text {th }}$ Annual Meeting of the European Association for Animal Production, Vienna, Austria, 25-28 Aug. 1997., Wageningen Pers, Wageningen, The Netherlands, (1997a), 279

BÖLCSKEY, K.; SÁRDI, J.; BOZÓ, S.; GYÖRKÖS, I.:

Effects of crossing with Belgian White-Blue breed on some meat characteristic. Book of Abstracts of the Satellite Symposium I. of the $48^{\text {th }}$ Annual Meeting of the European Association for Animal Production, held in Vienna, Austria, 25-28 Aug. 1997., 'Beef Production with special respect to beef quality', 23 Aug. 1997., Wageningen Pers, Wageningen, The Netherlands, (1997b), 85 
CARLSON, C.J.; BOOTH, F.W.; GORDON, S.E.:

Skeletal muscle myostatin mRNA expression is fiber-type specific and increases during hindlimb unloading. Am. J. Physiol., American Physiological Society, Bethesda, MD, USA, 277 (1999) (2 Pt 2), R601-606

CASAS, E.; KEELE, J.W.; FAHRENKRUG, S.C.; SMITH, T.P.; CUNDIFF, L.V.; STONE, R.T.:

Quantitative analysis of birth, weaning, and yearling weights and calving difficulty in Piedmontese crossbreds segregating an inactive myostatin allele. J. Anim. Sci., American Society of Animal Science, Savoy, IL, USA 77 (1999) 7, 1686-1692

CHARLIER, C.; COPPIETERS, W.; FARNIR, F.; GROBET, L.; LEROY, P.L.; MICHAUX, C.; MNI, M.; SCHWERS, A.; VANMANSHOVEN, P.; HANSET, R.; GEORGES, M.:

The mh gene causing double-muscling in cattle maps to bovine Chromosome 2. Mamm. Genome, Springer-Verlag, N.Y. Inc., New York, NY, USA 6 (1995), 788-792

CULLEY, G.:

Observations on Livestock. $4^{\text {th }}$ ed., G. WOODFALL, London, U. K. (1807)

CUNDIFF, L. V.; GREGORY, K.E.; WHEEKER, T.L.; SHACKELFORD, S.D.; KOOHMARAIE, M.; FREETLY, H.C.; LUNSTRA, D.D.:

Preliminary Results from Cycle V of the Cattle Germplasm Evaluation Program at the Roman L. Hruska Meat Animal Research Center. Germplasm Evaluation Program Progress Report No. 16. USDA Agricultural Research Service, Washington D.C., USA (1997)

DICKMAN, S.:

Gene mutation provides more meat on the hoof. Science, Am. Assoc. for the Adv. of Sci., Washington

DOHY, J.: D. C., USA 277 (1997) 5334, 1922-1923

Állattenyésztési genetika. (Animal breeding genetics). Mezőgazdasági Kiadó, Budapest, Hungary (1979), p. 44, In Hungarian

GIBSON, M. C., SCHULTZ, E.:

The distribution of satellite cells and their relationship to specific fiber types in soleus and extensor digitorum longus muscles. Anat. Rec., Wiley and Sons Inc., New York, NY, USA 202 (1982), 327-337

GROBET, L.; MARTIN, L.J.; PONCELET, D.; PIROTTIN, D.; BROUWERS, B.; RIQUET, J.; SCHOEBERLEIN, A.; DUNNER, S.; MENISSIER, F.; MASSABANDA, J.; FRIES, R.; HANSET, R.; GEORGES, M.:

A deletion in the bovine myostatin gene causes the double-muscled phenotype in cattle. Nat. Genet., Nature America Inc., New Zork, NY, USA 17 (1997) 1, 71-74

GROBET, L.; PONCELET, D.; ROYO, L. J.; BROUWERS, B.; PIROTTIN, D.; MICHAUX, C.; MENISSIER, F.; ZANOTTI, M.; DUNNER, S.; GEORGES, M.:

Molecular definition of an allelic series of mutations disrupting the myostatin function and causing double-muscling in cattle. Mamm. Genome, Springer-Verlag, N.Y. Inc., New York, NY, USA 9 (1998) $3,210-213$

HAMRICK, M. W.; MCPHERRON, A. C.; LOVEJOY, C. O.; HUDSON, J.:

Femoral morphology and cross-sectional geometry of adult myostatin-deficient mice. Bone, Elsevier Science Inc., New York, NY, USA, 27 (2000) 3, 343-349

HANSET, R., MICHAUX, C., DESSY-DOIZE, C., BURTONBOY, G.:

Studies on the $7^{\text {th }}$ rib in double muscled and conventional cattle. In: Current Topics in Veterinary Medicine and Animal Science, Vol. 16: Muscle Hypertrophy of Genetic Origin and its Use to Improve Beef Production. (Eds. KING and MÉNISSIER), Martinus Nijhoff Publishers, The Hague, The Netherlands (1982), pp. 341-349

HANSET, R.:

At the heart of the Belgian White-Blue genetics. Proceedings of the $5^{\text {th }}$ International Association of Belgian White-Blue Cattle Breeders Annual Meeting, Montebello, Quebec, Canada, October, 1997. (1997)

JI, S.; LOSINSKI, R.L.; CORNELIUS, S.G.; FRANK, G.R.; WILLIS, G.M.; GERRARD, D.E.; DEPREUX, F.F.S.; SPURLOCK, M.E.:

Myostatin expression in porcine tissues: tissue specificity and developmental and postnatal regulation. Am. J. Physiol. (Regulatory Integrative Comp. Physiol. 44) American Physiological Society, Bethesda, MD, USA 275 (1998), R1265-R1273

KAISER:

Über die sogenannten doppellendigen Rinder. Landw. Jb., 17 (1888), 387-403

KAMBADUR, R.; SHARMA, M.; SMITH, T.P.; BASS, J.J.:

Mutations in myostatin (GDF8) in double-muscled Belgian White-Blue and Piedmontese cattle.

Genome Res., Cold Spring Harbour Laboratory Press, New York, NY, USA 7 (1997) 9, 910-916

KIM, H.S.; LIANG, L.; DEAN, R.G.; HAUSMAN, D.B.; HARTZELL, D.L.; BAILE, C.A.: 
Inhibition of preadipocyte differentiation by myostatin treatment in 3t3-11 cultures. Biochem. Biophys. Res. Commun., Academic Press, San Diego, CA,USA 281 (2001) 4, 902-906

KINGSLEY, D.M.:

The TGF- $\beta$ superfamily: new members, new receptors, and new genetic tests of function in different organism. Genes Dev., Cold Spring Harbour Laboratory Press, New York, NY, USA 8 (1994), 133-146

KIRK, S.; OLDHAM, J.; KAMBADUR, R.; SHARMA, M.; DOBBIE, P.; BASS J.: Myostatin regulation during skeletal muscle regeneration. J. Cell Physiol., Wiley-Liss Inc., Philadelphia, USA 184 (2000) 3, 356-363

KOCAMIS, H.; MCFARLAND, D.C.; KILLEFER, J.:

Temporal expression of growth factor genes during myogenesis of satellite cells derived from the biceps femoris and pectoralis major muscles of the chicken. J. Cell Physiol., Wiley and Sons Inc., New York, NY, USA 186 (2001) 1, 146-152

LEE, S. J.; MCPHERRON, A.C.:

Myostatin and the control of skeletal muscle mass. Curr. Opin. Genet. Dev., Current Biology Publications, London, UK 9 (1999) 5, 604-607

MCPHERRON, A.C.; LAWLER, A.M.; LEE, S.J.:

Regulation of skeletal muscle mass in mice by a new TGF- $\beta$ superfamily member. Nature, Macmillan Magazines Ltd., London, U. K. 387 (1997), 83-90

MCPHERRON, A.C.; LEE, S.J.:

The transforming growth factor $\beta$ superfamily in Growth Factors and Cytokines in Health and Disease (Eds. D. LEROITH, and C. BONDY), JAI Press, Greenwich, U. K. (1996), 357-393

MCPHERRON, A.C.; LEE, S.J.:

Double muscling in cattle due to mutations in the myostatin gene. Proc. Natl. Acad. Sci., The Natl. Acad. of Sci., Washington D.C., USA, 94 (1997) 23, 12457-12461

MENDLER, L.; ZADOR, E.; VERHEYEN, M.; DUX, L.; WUYTACK, F.:

Myostatin levels in regenerating rat muscles and in myogenic cell cultures. J. Muscle Res. Cell. Motil., Chapman and Hall, London, UK 21 (2000) 6, 551-563

MÉNISSIER, F.:

Present state of knowledge about the genetic determination of muscular hypertrophy or the double muscled trait in cattle. In: Current Topics in Veterinary Medicine and Animal Science, Vol. 16: Muscle Hypertrophy of Genetic Origin and its Use to Improve Beef Production. (Eds. KING and MÉNISSIER), Martinus Nijhoff Publishers, The Hague, The Netherlands (1982), 387-428

RIOS, R.; CARNEIRO, I.; ARCE, V.M.; DEVESA, J.:

Myostatin Regulates Cell Survival during C2C12 Myogenesis. Biochem. Biophys. Res. Commun., Academic Press, San Diego, CA, USA 280 (2001) 2, 561-566

ROBERTS, S.B.; GOETZ, F.W.:

Differential skeletal muscle expression of myostatin across teleost species, and the isolation of multiple myostatin isoforms. FEBS Lett., Europ. Mol. Biol. Lab., Heidelberg, Germany; Elsevier Science BV, Amsterdam, The Netherlands 491 (2001) 3, 521-530

RODGERS, B.D.; WEBER, G.M.; SULLIVAN, C.V.; LEVINE, M.A.:

Isolation and Characterization of Myostatin Complementary Deoxyribonucleic Acid Clones from Two Commercially Important Fish: Oreochromis mossambicus and Morone chrysops. Endocrynology, Lippincot, Philadelphia, PA, USA 142 (2001) 4, 1412-1418

SAKUMA, K.; WATANABE, K.; SANO, M.; URAMOTO, I.; TOTSUKA, T.:

Differential adaptation of growth and differentiation factor 8/myostatin, fibroblast growth factor 6 and leukemia inhibitory factor in overloaded, regenerating and denervated rat muscles. Biochim. Biophys. Acta., Elsevier Science Ltd., Oxford, UK 1497 (2000) 1, 77-88

SHARMA, M.; KAMBADUR, R.; MATTHEWS, K.G.; SOMERS, W.G.; DEVLIN, G.P.; CONAGLEN, J.V.; FOWKE, P.J.; BASS, J.J.:

Myostatin, a transforming growth factor-beta superfamily member, is expressed in heart muscle and is upregulated in cardiomyocytes after infarct. J. Cell. Physiol., Wiley and Sons Inc., New York, NY, USA 180 (1999) 1, 1-9

SLACK, J.M.:

Growth control: action mouse. Curr. Biol., Current Biology Ltd., London, UK 7 (1997) 8, R467-469

SMITH, T.P.; LOPEZ-CORRALES, N.L.; KAPPES, S.M.; SONSTEGARD, T.S.:

Myostatin maps to the interval containing the bovine mh locus. Mamm. Genome, Springer-Verlag N.Y. Inc., New York, NY, USA, 8 (1997) 10, 742-744

SONSTEGARD, T.S.; ROHRER, G.A.; SMITH, T.P.:

Myostatin maps to porcine chromosome 15 by linkage and physical analyses. Anim. Genet., Blackwell Science, Oxford, U. K. 29 (1998) 1, 19-22

STRATIL, A.; KOPECNY, M.: 
Genomic organization, sequence and polymorphism of the porcine myostatin (GDF8; MSTN) gene. Anim. Genet., Blackwell Science, Oxford, UK 30 (1999) 6, 468-470

SZABO, G.; DALLMANN, G.; MULLER, G.; PATTHY, L.; SOLLER, M.; VARGA, L.:

A deletion in the myostatin gene causes the compact (Cmpt) hypermuscular mutation in mice. Mamm. Genome., Springer-Verlag N.Y. Inc., New York, NY, USA 9 (1998) 8, 671-672

TAYLOR, W.E.; BHASIN, S.; ARTAZA, J.; BYHOWER, F.; AZAM, M.; WILLARD, D.H.; KULL, F.C.; GONZALEZ-CADAVID, N.:

Myostatin inhibits cell proliferation and protein synthesis in $\mathrm{C}(2) \mathrm{C}(12)$ muscle cells. Am. J. Physiol. Endocrinol. Metab., American Physiological Society, Bethesda, MD, USA 280 (2001) 2, E221-E228

THOMAS, M.; LANGLEY, B.; BERRY, C.; SHARMA, M.; KIRK, S.; BASS, J.; KAMBADUR, R.:

Myostatin, a negative regulator of muscle growth, functions by inhibiting myoblast proliferation. J. Biol. Chem., Am. Soc. for Biochem. and Mol. Biol., Baltimore, MD, USA 275 (2000) 51, 40235-40243

VARGA, L.; SZABÓ, GY.; DARVASI, A.; MÜLLER, G.; SASS, M.; SOLLER, M:

Inheritance and mapping of compact (Cmpt), a new mutation causing hypermuscularity in mice. Genetics, Genetics Society of America, USA 147 (1997), 755-764

WEHLING, M.; CAI, B.; TIDBALL, J.G.:

Modulation of myostatin expression during modified muscle use. FASEB J., Fed. Am. Soc. for Exp. Biol., Bethesda, MD, USA 14 (2000) 1, 103-110

WESTHUSIN, M.:

From mighty mice to mighty cows. Nat. Genet., Nature America Inc., New York, NY, USA 17 (1997) $1,4-5$

YAMANOUCHI, K.; SOETA, C.; NAITO, K.; TOJO, H.:

Expression of myostatin gene in regenerating skeletal muscle of the rat and its localization. Biochem. Biophys. Res. Commun., Academic Press, San Diego, CA, USA 270 (2000) 2, 510-516

Received: 2001-04-01

Accepted: 2002-02-28

Author's address

JULIANNA KOBOLÁK, M.Sc.

in Agricultural Sciences

Laboratory of Embriology

Agricultural Biotechnology Center

Gödöllő, POB:411, Hungary

E-Mail:kobolak@abc.hu 